\title{
TXNRD1 Gene
}

National Cancer Institute

\section{Source}

National Cancer Institute. IXNRD1 Gene. NCI Thesaurus. Code C107616.

This gene plays a role in the maintenance of cellular redox signaling. 